\title{
One Man, One Vote and Selection of Delegates to National Nominating Conventions
}

After eight years of decisions and copious commentary, the impact of the reapportionment cases on political parties remains unclear. Whether the one man, one vote standard developed by the Court since Baker v. Carr ${ }^{1}$ should be imposed on political parties is a question that has arisen most pointedly in regard to selection of delegates to national nominating conventions. ${ }^{2}$

The argument for imposing the criterion of one man, one vote-or more precisely, one party member, one vote-on delegate selection can be briefly summarized. ${ }^{3}$ The reapportionment cases hold that dilution of voting power is a denial of equal protection under the fourteenth amendment and a violation of the right to vote. ${ }^{4}$ Districting schemes

1369 U.S. 186 (1962). The decisions spawned by Baker include: Hadley v. Junior College District, 90 S. Ct. 791 (1970); Kirkpatrick v. Preisler, 394 U.S. 526 (1969); Wells v. Rockefeller, 394 U.S. 542 (1969); Avery v. Midland County, 390 U.S. 474 (1968); Dusch v. Davis, 387 U.S. 112 (1967); Sailors v. Board of Educ., 387 U.S. 105 (1967); Swann v. Adams, 385 U.S. 440 (1967); Fortson v. Morris, 385 U.S. 231 (1966); Burns v. Richardson, 384 U.S. 73 (1966); Lucas v. Forty-Fourth Gen. Assembly of Colo., 377 U.S. 713 (1964); Roman v. Sincock, 377 U.S. 695 (1964); Davis v. Mann, 377 U.S. 678 (1964); Maryland Comm. for Fair Representation v. Tawes, 377 U.S. 656 (1964); WMCA, Inc. v. Lomenzo, 377 U.S. 633 (1964); Reynolds v. Sims, 377 U.S. 533 (1964); Wesberry v. Sanders, 376 U.S. 1 (1964); Gray v. Sanders, 372 U.S. 368 (1963). The most complete discussion of the one man, one vote problem yet to appear is $R$. Dixon, Democratic REPRESENTATION: REAprortionment in Law and Polmics (1968). See also G. Baker, The Reapportionment Reyolution (1966).

2 See Irish v. Democratic-Farmer-Labor Party, 287 F. Supp. 794 (D. Minn.), aff'd per curiam, 399 F.2d 119 (8th Cir. 1968); Smith v. State Executive Comm., 288 F. Supp. 371 (N.D. Ga. 1968); Dahl v. Republican State Comm., Civil No. 7557 (W.D. Wash. 1968), vacated and remanded, 393 U.S. 408 (1969). In other cases, the question has arisen in regard to elections to choose party committee members. Lynch v. Torquato, 343 F.2d 370 (3d Cir. 1965); Rogers v. State Comm. of the Republican Party, 96 N.J. Super. 265, 232 A.2d 852 (1967); Davis v. Sullivan, 47 Misc. 2d 60, 261 N.Y.S.2d 697 (1965).

3 The argument, or a variant thereof, is made in: Comment, Constitutional Reform of State Delegate Selection to National Political Party Conventions, 64 Nw. U.L. REv. 915 (1970); Note, Constitutional Safeguards in the Selection of Delegates to Presidential Nominating Conventions, 78 YALE L.J. 1228 (1969); Note, The Presidential Nomination: Equal Protection at the Grass Roots, 42 S. GAL. L. Rev. 169 (1969); Note, Regulation of Political Parties: Vote Dilution in the Presidential Nomination Procedure, 54 Iowa L. Rev. 471 (1968); Hungry Democrats, The NEw RepUbLIC, Sept. 27, 1969, at 12; cf. testimony of Dean Louis Pollak of Yale University Law School speaking on behalf of Connecticut challengers before the Credentials Committee at the 1968 Democratic National Convention, Cong. Quar. Service, The Presidential Nominating Conventions 1968, at 103 (1968).

4 See, e.g., Reynolds v. Sims, 377 U.S. 533 (1964). 
which vary from the principle of numerical equality are invalid as a dilution of the voting power of those who live in more populous districts. ${ }^{5}$ Neither major party chooses its national convention delegates in accordance with the mathematically precise standards of the reapportionment cases, ${ }^{6}$ with the result that some of those participating in the delegate selection process are underrepresented at this stage of the nomination process. Since nomination is an integral part of the presidential election process, these inequalities dilute the vote for the presidency itself. To avoid this alleged discrimination in voting power, the constitutional principles applicable to other electoral processes are similarly applicable to delegate selection. The application of these principles, it is concluded, would secure effective popular control of the presidential nominating process.

When pressed upon the courts this argument has so far been unsuccessful. $^{7}$ Despite efforts by the parties to "democratize" the delegate selection process, ${ }^{8}$ it is likely to be pressed again when a party's endorsement of a presidential candidate is once more at stake.

This comment takes the position that the one man, one vote formula should continue to be rejected in the context of delegate selection for three reasons. First, the fourteenth amendment's requirement of state action and the requirement that a controversy be justiciable are less easily satisfied with respect to delegate selection than with respect to other aspects of the election process. Second, the national conventions serve a role distinct from that of the governmental agencies with which

5 Kirkpatrick v. Preisler, 394 U.S. 526, 530-1 (1969), requires "a good faith effort to achieve precise mathematical equality." See also Wells v. Rockefeller, 394 U.S. 542 (1969).

c Both major parties allow each state at least as many delegates as it has members of Congress. Since senators are not assigned on a population basis, party members from smaller states are "over-represented" by this method of allocating delegates. The two national committee members of each state are also given delegate status. The distortion is further increased by the allowance of "bonus votes" for success in previous elections. For a more detailed analysis of deviation from mathematical equality in the allocation of convention votes, see note 89 infra.

7 Cases cited note 2 supra.

8 In 1968, the Democrats adopted a resolution providing:

It is understood that a state Democratic party, in selecting and certifying delegates to the National Convention, thereby undertakes to assure that such delegates have been selected through a process in which all Democratic voters have had full and timely opportunity to participate. In determining whether a state party has complied with this mandate, the convention shall require that:

(1) The unit rule not be used at any stage of the delegate selection process; and

(2) All feasible efforts have been made to assure that delegates are selected through party primary, convention, or committee procedures open to public participation within the calendar year of the National Convention.

Cong. Quar. Service, The Presidential Nominating Conventions 1968, at 148, 197 (1968). This resolution signals far reaching changes in selection of delegates in the Democratic Party. For a description and analysis of these changes, see Schmidt \& Whalen, Credentials Contests at the 1968-And 1972-Democratic National Conventions, 82 Harv. L. Rev. 1498 (1969). 
the reapportionment cases have been concerned, and this creates a special set of problems not yet faced by the courts. Third, reforming the delegate selection process by application of the one man, one vote principle would hamper performance of the important functions the national conventions now serve.

Analysis of each of these propositions is complicated by the two level structure of delegate selection: first, the selection of national convention delegates by the state parties and, second, the apportionment of delegates among the states by the national parties. ${ }^{9}$ Equal voting power of party members in the overall delegate selection process could be effected only by application of one man, one vote at both of these levels. Because distinct problems arise at each level of delegate selection, these two levels will be considered separately in examining the arguments for and against application of the one man, one vote standard to selection of national convention delegates.

\section{Preliminary Investigations: State Action and the Political Question DocTrine}

\section{A. State Action}

It is questionable whether there is much vitality left in the state action limitation on application of the fourteenth amendment. ${ }^{10} \mathrm{Im}$ precise and expansive notions of state involvement, ${ }^{11}$ state regulation, ${ }^{12}$ and governmental or public functions ${ }^{13}$ have been used to extend the ambit of state action, without the corresponding development of a limiting concept. About all that can be said with certainty and accuracy is that state action is circumscribed by very liberal borders. The expansion of the state action concept has been most striking in the context of racial discrimination. ${ }^{14}$ Indeed, some commentators feel that one

9 It should be noted that a state Democratic party may have more delegates than it has convention votes. The Democrats permit fractional voting, although no delegate may have less than one half vote. In the Republican convention each delegate casts one vote. The textual references to allocation of delegates to the state parties by the national party will assume that each delegate has one vote.

10 One authority calls state action "a conceptual disaster area." Black, The Supreme Court-Foreword, 81 HARv. L. REv. 69, 95 (1967). See generally Developments in the Law -Equal Protection, 82 HARv. L. REv. 1065, 1069-72 (1969); Silard, A Constitutional Forecast: Demise of the "State Action" Limit on the Equal Protection Guarantee, 66 Colum. L. Rev. 855 (1966).

11 See Burton v. Wilmington Parking Authority, 365 U.S. 715 (1961); Shelley v. Kraemer, 384 U.S. 1 (1948).

12 Cf. Public Utilities Comm'n v. Pollak, 343 U.S. 451 (1952).

13 See Evans v. Newton, 382 U.S. 296 (1966); Marsh v. Alabama, 326 U.S. 501 (1946).

14 See, e.g., Evans v. Newton; 382 U.S. 296 (1966); Burton v. Wilmington Parking Authority, 365 U.S. 715 (1961). 
case involving a claim of racial discrimination in the conduct of a primary by a local political party may have read out this ingredient altogether. ${ }^{15}$ The White Primary Cases ${ }^{16}$ repeatedly found state action in the conduct of primary elections and intervened to prohibit racial discrimination.

There would seem to be little reason why this loose standard of state action should be constricted when there is no claim of racial discrimination but the situation is otherwise factually similar. Thus, though no claim of racial discrimination was made in Gray $v$. Sanders, ${ }^{17}$ the Court had no difficulty in finding state action and applying one man, one vote principles to invalidate use of the unit vote in a Georgia primary to select nominees for the United States Senate and other statewide offices. It might be further argued that the Court's finding of state action in these primary cases was determined by the presence, in each case, of a one-party system, where the party primary predetermined the general election victor. ${ }^{18}$ Such predetermination is absent in the delegate selection situation. Without a more explicit indication from the Court that predetermination of the general election is a significant factor in finding state action in primary elections, this factual distinction would probably not frustrate a finding of state action in the selection of national convention delegates through primary elections; for the degree of state involvement and regulation of one-party state primaries is the same as that of delegate selection primaries. ${ }^{19}$

15 The case is Terry v. Adams, 345 U.S. 461 (1953). Mr. Justice Harlan noted this in his dissent in Evans v. Newton, 382 U.S. 296, 320 n.5 (1966), citing Lewis, The Meaning of State Action, 60 Colum. L. REv. 1083, 1094 (1960) and Note, The Strange Career of "State Action" Under the Fifteenth Amendment, 74 YALE L.J. 1448, 1456-9 (1965).

16 Terry v. Adams, 345 U.S. 461 (1953); Smith v. Allwright, 321 U.S. 649 (1944); United States v. Classic, 313 U.S. 299 (1941); Nixon v. Condon, 286 U.S. 73 (1932); Nixon v. Herndon, 273 U.S. 536 (1927); Baskin v. Brown, 174 F.2d 391 (4th Cir. 1949); Rice v. Elmore, 165 F.2d 387 (4th Cir. 1947).

17372 U.S. 368 (1963).

18 It is difficult to assess exactly how much weight was accorded this factor. The Court seems to rely on it heavily. See, e.g., Terry v. Adams, 345 U.S. 461,469 (1953), where Mr. Justice Black pointed out that "[t]he Democratic primary and the general election have become no more than the perfunctory ratifiers of the choice that has already been made in Jaybird elections . . . ."; Gray v. Sanders, 372 U.S. 368, 380 (1963); United States v. Classic, 313 U.S. 299, 313-4 (1941); Baskin v. Brown, 174 F.2d 391, 392 (4th Cir. 1949). On the other hand, the Court points to other grounds for finding state action in primaries. Smith v. Allwright, 321 U.S. 649, 663 (1944), indicates that primaries are conducted by the party under state statutory authority and that this is grounds for designating the party a state agency. Also, the Court's statement, for example, in Smith v. Allwright that "[w]hen primaries become a part of the machinery for choosing officials, state and national, as they have here, the same tests to determine the character of discrimination or abridgement should be applied to the primary as are applied to the general election," would seem to carry it beyond primaries in which predetermination is involved. Id. at 664 .

19 In California, Florida, Massachusetts, Nebraska, New Hampshire, New Jersey, Ohio, 
In the majority of states, where parties choose delegates through state conventions or executive committees, ${ }^{20}$ the presence of state action is not so clear. ${ }^{21}$ Three lower federal courts have indicated that no state action is involved in the conduct of intraparty affairs. In Lynch $v$. Torquato, ${ }^{22}$ the Court of Appeals for the Third Circuit refused relief to registered Democrats who alleged a denial of equal protection in the selection of the members and chairman of a county Democratic committee. Two committee members were chosen from each precinct despite differences in the number of Democratic voters in each precinct. The court said that "the normal role of party leaders in conducting internal affairs of their party ... does not make their party offices or the filling of these offices state action ...."23

Lynch explicitly left open the question whether state action would be present in a case in which a party officer is empowered to nominate candidates for political office. ${ }^{24}$ Four years later two other courts in examining this question likewise indicated that the state action requirement of the fourteenth amendment had not been satisfied. In considering a challenge of malapportionment in the selection of Democratic national convention delegates from Minnesota, the district court in Irish $v$. Democratic-Farmer-Labor Party ${ }^{25}$ held that the alleged malapportionment was a "result of . . . the constitution of the DFL as a political party, not the by-product or result of any state statutes or state constitutional provision," 26 even though state statutes recognized the party and vested final authority over party affairs in the state convention. ${ }^{27}$ Similarly, Smith v. State Executive Committee ${ }^{28}$ held that in

Oregon, South Dakota, West Virginia, and the District of Columbia, all delegates are chosen by primary. In Illinois, New York, and Pennsylvania only district delegates are so chosen. Alabama Democrats select national convention delegates by primary. See U.S. Cong. Sen. Lubrary, Nomination and Election of the President and Vice President of THE UNITED States (1968).

20 In thirty-five states, all delegates are chosen by these party organs. Some states use a hybrid system of selection. For example, New York parties choose congressional district delegates at a primary while delegates at large are chosen by the party state committee or state convention, as the rules of the party prescribe. N.Y. ElEction LAw \& 21. See also IIL. REv. STAT. ch. 46, \$§ 7-1, 7-5, 7-9(b) (1967). A detailed statement of delegate selection procedures is presented in U.S. Cong. SEN. LIBRARY, Nomination aNd Election of the President and Vice President of the United States (1968).

21 Gray v. Sanders, 372 U.S. 368, 378 n.10 (1963), states: "We do not here reach the questions that would be presented were the convention system used for nominating candidates in lieu of the primary system."

22343 F.2d 370 (3d Cir. 1965).

23 Id. at 372 .

24 Id. at 373.

25287 F. Supp. 794 (D. Minn.), affd per curiam, 399 F.2d 119 (8th Cir. 1968).

26 Id. at 801 .

27 Id. at 798.

28288 F. Supp. 371 (N.D. Ga. 1968). 
the selection of delegates to the Democratic National Convention, "No action by the state is involved ... and no state officer is concerned." 29

To the extent that these decisions are accepted as authoritative considerations of state action, the anomalous result is that selection of delegates will constitute state action in states which choose delegates at primaries but not in states which choose delegates by other methods. There is reason to believe, however, that Smith and Irish will be regarded as less than authoritative in their treatment of the state action question. Neither court relied heavily on its state action findings, preferring to concentrate on other justifications for refusing to apply one man, one vote to political parties. ${ }^{30}$ The perfunctory discussions of the state action question in the two cases may have been due to a reluctance to rest their decision on the conceptual quicksand of state action. The question of state action in delegate selection can be approached more systematically by examining the extent of state regulation of delegate selection and by considering whether delegate selection is a state or public function.

1. State Action Through Government Regulation of Delegate Selection. To the extent that activities which would otherwise be characterized as private are pursued in accordance with a state regulatory statute so that legal consequences are attributed to these activities, state action is involved. ${ }^{31}$ In those states whose statutes prescribe the organizational structure of the party within the state, the powers and duties of different party assemblies, the composition of the state executive committee and convention, the time and place for committee and convention meetings, the terms of office of party officials, the selection of national convention delegates, and the reporting of party finances, ${ }^{32}$ a finding of state action would be justified. At the other extreme are states which

29 Id. at 374.

30 Among these are the lack of "judicially discoverable and manageable standards," inappropriateness of the relief sought, and the possibility that one man, one vote requirements had in fact been satisfied by allowing full and equal participation at the level of precinct meetings. See Irish v. Democratic-Farmer-Labor Party, 287 F. Supp. 794, 803-7 (D. Minn.), aff'd per curiam, 399 F.2d 119 (8th Cir. 1968). Smith v. State Executive Comm., 288 F. Supp. 371, 376 (N.D. Ga. 1968), points to a complete lack of authority for assuming jurisdiction over the internal affairs of a political party.

31 "Conduct that is formally 'private' may become so entwined with governmental policies or so impregnated with a governmental character as to become subject to the constitutional limitations placed upon state action." Evans v. Newton, 382 U.S. 296, 299 (1966). When state statutes are followed by the parties, "legal consequence is given to the activities of private parties ...." Developments in the Law-Equal Protection, supra note 10, at 1072.

32 See, e.g., ARIz. REv. Stat. ANN. \$\$ 16-201 to 16-239 (1956); IDAHo Code ANN. §§ 34-601 to 34-649 (1949); IND. ANN. STAT. $\$ \$ 29-2901$ to 29-2903, 29-3701 to 29-3705 (1969); KAN. GEN. STAT. ANn. \&\& 25-221, 25-223 (Supp. 1969). 
attempt no regulation of political parties. ${ }^{33}$ In these states, state action through state regulation is not present. Several other states lie between the two extremes. ${ }^{34}$ The search for state action in government regulation of the parties thus becomes essentially a factual inquiry, the results of which will vary from state to state.

2. State Action in the Allocation of Delegates. At the second level of the delegate selection process-the allocation of delegates to the state parties by the national party-it may be more difficult to find state action through government regulation. The national convention, ungoverned by state or federal statutes, determines rules for such allocation. These rules ${ }^{35}$ are not keyed to the number of party members per state. ${ }^{36}$ Since the national parties have remained virtually free of direct state or federal regulation, state action on the part of the national conventions would have to be based on an imputation of state action of the several state parties to the deliberations of national party organs. ${ }^{37}$ The national party is not, however, simply an agent of the state parties. The national party organs exercise powers that no state or state party possesses: they issue the call for a convention, hear and decide credentials contests, determine rules of procedure, select temporary officers, and elect national officers. The allocation of delegates is itself a power of the national party which no state party could exercise. In performing these functions, the national party is not subject to even indirect state statutory regulation.

3. State Action Through Performance of a "Governmental Function." An alternative approach to a finding of state action would be to determine that nomination of a presidential candidate is a function "governmental in nature." 38 The historical evidence on this score is inconclusive. ${ }^{39}$ However, both precedent and analysis strongly suggest

33 This is the situation for example in Alaska, Delaware, Georgia, and Kentucky.

34 Cf. ARk. Stat. ANN. $\S 3201$ to $3-319$ (1956); ConN. Gen. Stat. $\$ \S 9-372$ to 9-461 (1958); MINN. StAT. §§ 202-20 to 202-27 (1962).

35 See rules mentioned note 6 supra; A. Bickel, The New Age of Polmical Reform 37-39 (1968).

36 This is assuming that the basis for determining who shall have an equal vote in delegate selection will be the number of registered party members in the state. On problems of determining what basis to use for insuring equal voting power see text infra, at notes 83-91.

37 See Note, Regulation of Political Parties: Vote Dilution in the Presidential Nomination Procedure, 54 Iowa L. REv. 471, 477 (1968).

38 Evans v. Newton, 382 U.S. 296, 299 (1966).

39 See M. Jensen, The Making of the AMERICAN Constriution 111-4 (1964). Jensen notes that it was a common assumption among the Constitution's draftsmen that, after the first election which Washington was sure of winning, the Electoral College would seldom cast a majority vote for any one man, and that the election would then be decided in the House of Representatives. In such a situation, the role of the Electoral College would essentially be one of nominating candidates. From this historical setting, one com- 
that nomination of presidential candidates is a governmental rather than a private function. Since conduct of elections is clearly a state function ${ }^{40}$ and nominations are an integral part of the electoral process, one might argue that the organizations which nominate candidates are performing a state function. This "integral relation" argument has been successful in the White Primary Cases ${ }^{41}$ and in Gray v. Sanders. ${ }^{42}$ The relation between the primary and election was especially "integral" in these cases because the primaries involved state offices and predetermined the outcome of the general election.43 In delegate selection, however, no state office is immediately involved, ${ }^{44}$ and there is no predetermination of the election victor.

Another aspect of nomination that makes it appear to be more like a private function than a governmental function is that the process of nomination is generally carried on by individuals in their role as private citizens. When a citizen, unaffiliated with a party or organized group, puts himself up for political office, it would be difficult to find state action in his candidacy. That the function of nomination is not readily taken out of the hands of private citizens is illustrated by the situation in one-party states that have imposed primary elections on the nomination process; there is in these states the formation of competing groups-party factions ${ }^{45}$ - which organize to appeal to primary voters. Thus, a campaign battle between nomination contenders is fought before the state imposed structures come into play. Imposition of state structures on nomination does not end the private role of individuals in nominating candidates; it merely pushes the role of private action back a step. ${ }^{46}$

mentator argues that the states, because they are given the power to choose electors, were meant to control the nomination of presidential candidates. Since nomination of electors is universally delegated by the states to the parties, this argument concludes that the parties are performing a state function. Note, Regulation of Political Parties: Vote Dilution in the Presidential Nomination Procedure, 54 Iowa L. REv. 471, 472-3 (1968). This argument would be more plausible if selection, rather than nomination of electors had been delegated to the parties. Also, it ignores the development by the parties of a completely separate device for nominating candidates long before nomination of electors was delegated to the parties.

40 Terry v. Adams, 345 U.S. 461 (1953).

41 Cases cited note 16 supra.

42372 U.S. 368 (1963). See also Newberry v. United States, 256 U.S. 232, 285.6 (1921) (concurring opinion of Mr. Justice Pitney).

43 See discussion note 18 supra.

44 Cases cited note 55 infra.

$45 \mathrm{~V}$. O. Key hints that the same breakdown can occur in two party states: "Wide-open primaries tend both to shatter party organization and to leave it without much of anything to do." V.O. Key, American State Polmics: AN INTRoduction 288 (1956).

40 A basic description of the operation of factionalized party systems is found in $F$. Greenstein, The American Party System and the American People 60-68 (1963). 
Yet, the presidential nomination system does effectively narrow the electoral choice to two. The state acquiesces in and gives legal effect to this narrowing process by placing the candidate's name on the ballot. In so doing, the state adopts party processes as part of its electoral scheme. This phenomenon is clearest in one-party states where nomination is tantamount to election so that the general election is rendered meaningless. The effect is not as aggravated in presidential elections, but the actions of the major parties in choosing candidates severely limit the element of choice in the general election; ${ }^{47}$ it is certainly arguable that this narrowing process bears an "integral" enough relation to the general election so as to constitute state action.

4. The "Governmental Official" Limitation on One Man, One Vote. Because state involvement in general elections is undenied, there has been little discussion of state action in the reapportionment cases. A related inquiry results, however, from the Supreme Court's reluctance to extend the one man, one vote principle beyond the popular election of governmental officials. ${ }^{48}$ The governmental duties performed by the official need not be broad. In Hadley $v$. Junior College District, ${ }^{49}$ the Court rejected examination of the functions performed by an official as a test for deciding whether to apply the one man, one vote standard.50 Instead, it would apply equal protection principles to any popular election of a government official. ${ }^{.1}$ But the Court equivocated: "It is of course possible that there might be some case in which a State elects certain functionaries whose duties are so far removed from normal governmental activities ... that a popular election in compliance with Reynolds [v. Sims] . . might not be required . . . ."52 It would appear, therefore, that while the boundaries of one man, one vote are not yet precisely defined, there is a minimal requirement that activities with some governmental character be involved.

One essential element of governmental activity-the ability to resort to coercion to enforce governmental objectives-is absent with regard to national conventions. Party members cannot be forced to follow the

47 This sort of reasoning is akin to the "structural" type of analysis described in C. BLAck, STRUGTURE AND RELATIONSHIP IN Constitutional LAW (1969). It leaves open the possibility that operation of minor parties (e.g., the Socialist Party or Wallace's American Independent Party) would not involve a governmental function and thus not be state action.

48 See, e.g., Sailors v. Board of Educ., 387 U.S. 105, 109-10 (1967); In re Sullivan, 283 Ala. 514, 522, 219 So. 2d 346, 352 (1969); Sullivan v. Alabama State Bar, 295 F. Supp. 1216, 1222 (M.D. Ala.), aff'd per curiam, 394 U.S. 812 (1969); cf. Fortson v. Morris, 385 U.S. 231 (1966).

4990 S. Ct. 791 (1970).

$50 \mathrm{Id}$. at 795 .

51 Id.

$52 I d$. 
convention's dictates. In the tightly competitive system generally characteristic of presidential election politics, a party member can switch his support to the opposing party and still have a substantial chance of backing the successful candidate. Further, he is not necessarily locked into a choice between two parties. ${ }^{53}$ Though a third party candidate has slight chance of winning the presidency, a strong third party organization can often force the major parties to adopt some of its policy views. ${ }^{54}$

It would be a distortion of common understanding to call delegates state or governmental officials. Both the Smith and Irish courts held that delegates are not state officers. ${ }^{55}$ Delegates are involved in an endeavor to gain or retain political power rather than in an exercise of political power through control of governmental activities and performance of governmental duties.

\section{B. The Political Question Doctrine}

The political question limitation on judicial intervention, said to involve the "justiciability" of a controversy, ${ }^{56}$ has been severely narrowed since Baker v. Carr.57 Baker explains that a "political question" can arise only when, as a minimum requirement, ${ }^{58}$ a controversy deals with "the relationship between the judiciary and the coordinate branches of the Federal Government."59

It is doubtful that in reviewing delegate selection procedures the judiciary would be infringing on the exclusive sphere of either the Executive or Congress. ${ }^{60}$ Nevertheless, lower federal courts have refused to consider challenges to apportionment in delegate selection on the grounds that it involved a "political question." 61 In these cases, the

53 The Supreme Court has recently facilitated third party access to the ballot. See Moore v. Ogilvie, 394 U.S. 814 (1969); Williams v. Rhodes, 393 U.S. 23 (1968).

54 A. BiCKEL, supra note 35 , at $42-43$.

55 Smith v. State Executive Comm., 288 F. Supp. 371, 374 (N.D. Ga. 1968); Irish v. Democratic-Farmer-Labor Party, 287 F. Supp. 794, 797 (D. Minn.), affd per curiam, 399 F.2d 119 (8th Gir. 1968).

56 Baker v. Carr, 369 U.S. 186, 208-37 (1962).

57 See, e.g., Powell v. McCormack, 395 U.S. 486 (1969); Williams v. Rhodes, 399 U.S. 23 (1968).

58 If this requirement of the political question doctrine is met, the court also considers “" the appropriateness under our system of government of attributing finality to the action of the political departments and also the lack of satisfactory criteria for a judicial determination." " 369 U.S. 186, 210 (1962).

59 Id.

60 Neither Congress nor the Executive presently supervises delegate selection procedures, though there may be no constitutional bar to Congress doing so. Cf. Claude, Nationalization of the Electoral Process, 6 HARv. J. LEGIs. 139 (1969).

61 Irish v. Democratic-Farmer-Labor Party, 287 F. Supp. 794 (D. Minn. 1968), aff'd, 399 F.2d 119, 121 (8th Cir. 1968); cf. Smith v. State Executive Comm., 288 F. Supp. 371 (N.D. Ga. 1968). 
political question doctrine may be an inappropriate label for an appropriate consideration. What these courts were concerned with was not a political question but rather the "lack of judicially manageable standards" for judicial decision, which Baker pointed to as one of the characteristic features of a political question. ${ }^{62}$ For example, if the court had decided the controversy in Irish $v$. Democratic-Farmer-Labor Party ${ }^{63}$ it would have determined whether Humphrey delegates should be replaced by McCarthy delegates. ${ }^{64}$ In Smith v. State Executive Committee, ${ }^{65}$ the court would have determined that a slate of delegates already chosen could not be seated at the national convention. There were no clear standards for choosing between the competing groups; and since the Democratic Convention was imminent at the time both of these suits were decided, ${ }^{6 B}$ the courts were understandably reluctant to make a decision that might affect the outcome of the convention deliberations. ${ }^{\text {it }}$

Moreover, the courts were justified on precedential grounds in refusing to consider the controversies, since judicial interference in intraparty affairs has not gone beyond cases of racial discrimination or cases where the party selection predetermined the election..$^{68}$ As the Smith court noted, "there is no known case to the effect that any jurisdiction exists over the internal rules or management of a political party." 69

It has nevertheless been argued that had the complaints in Irish and

62369 U.S. 186, 217 (1962).

63399 F.2d 119 (8th Cir.), aff'g 287 F. Supp. 794 (D. Minn. 1968).

64 See report of the Minnesota credentials dispute in Cong. Quar. Service, The PresiDENTIAL Nominating Conventions 1968, at 102-3 (1968).

65288 F. Supp. 371 (N.D. Ga. 1968).

66 The Democratic National Convention began on Aug. 26, 1968. Irish was decided by the Court of Appeals Aug. 13, 1968, and Smith was decided Aug. 23, 1968.

67 The Irish court also considered the availability of intraparty grievance structures as a justification for refusing to grant relief. 399 F.2d 119, 121 (8th Cir. 1968).

68 The only Supreme Court case dealing directly with interference in the affairs of political parties is Ray v. Blair, 343 U.S. 214 (1952). The Court refused to invalidate a requirement that candidates for presidential elector take a pledge to support their party's presidential nominee. Said the Court, "The fact that the primary is a part of the election machinery is immaterial unless the requirement violates some constitutional or statutory provision." Id. at 227. This is the ground on which the case was distinguished from the White Primary Cases, note 16 supra.

The majority rule in state courts appears to be that expressed in Democratic-FarmerLabor Party State Cent. Comm. v. Holm, 227 Minn. 52, 55, 33 N.W.2d 831, 833 (1948): "[I]n factional controversies within a political party, where there is involved no controlling statute or clear right based on statute law, the courts will not assume jurisdiction, but will leave the matter for determination within the party organization." See also Smith v. McQueen, 232 Ala. 90, 166 So. 788 (1936); State ex rel. Robinett v. Jarrett, 200 Okla. 387, 196 P.2d 849 (1948); Tuck v. Cotton, 175 Ark. 409, 299 S.W. 613 (1927); Lasseigne v. Martin, 202 So. $2 d 250$ (Ct. App. La. 1967); Carter v. Tomlinson, 149 Tex. 7, 227 S.W.2d 795 (1950). But see State ex rel. Buttz v. Marion Cir. Ct., 225 Ind. 7, 72 N.E.2d 225 (1947).

69288 F.2d at 376. 
Smith been more timely-brought before any delegates had actually been selected-judicial relief would have been appropriate. ${ }^{70}$ But the consideration which gave the courts pause in Irish and Smith is not absent before delegates are chosen. Any decision concerning delegate selection would have two sets of impacts. First, it would affect the immediate balance of power between competing party factions. Secondly, and more importantly, a judicial decision to impose one man, one vote standards on parties could effect changes in the operation of the political system itself. ${ }^{71}$ Judicially manageable standards for dealing with either of these impacts have not yet been developed.

\section{Application of the One Man, One Vote Principle to Delegate Selection}

Two elements of one man, one vote doctrine generate unique problems in applying the doctrine to delegate selection. The first is the demand for perfect mathematical equality of voting power; the second is that the one man, one vote doctrine developed to deal with governmental bodies. This section examines the effects of applying a doctrine with these two qualities to selection of national convention delegates.

\section{A. "Legitimate Party Interests" in Unequal Apportionment of Dele- gates}

The reapportionment cases suggested that there are legitimate state interests which might justify slight ${ }^{22}$ deviations from mathematical equality. ${ }^{73}$ The range of countervailing interests in legislative reapportionment situations is limited. ${ }^{74}$ Whether these same interests are legitimate as applied to political parties has not been passed upon by any court. But party activities, unlike normal governmental activities, are commonly directed toward the promotion of an identifiable set of

70 Schmidt \& Whalen, Credentials Contests at the 1968-And 1972-Democratic National Conventions, 82 HARv. L. REv. 1438, 1449 n.46 (1969).

71 What the effects of imposing one man, one vote strictures on the parties and nomination process are likely to be is considered in Part III infra.

72 The leeway is not broad. In Kirkpatrick v. Preisler, 394 U.S. 526 (1969), the Court found no "Iegally acceptable justification" for a variance as small as 3.13 per cent from arithmetic equality.

73 Id. at 532. The Court reiterated its statement in Swann v. Adams, 385 U.S. 440, 443-4 (1967), that a state has the burden "to present ... acceptable reasons for the variations among the populations of the various ... districts ...." Id.

74 Mr. Justice Harlan's dissent in Reynolds v. Sims, 377 U.S. 533, 622-3 (1964), specifies the interests to which the Court will give no quarter: history; economic or other group interests; area; geographical considerations; a desire to insure effective representation for sparsely settled areas; availability of access of citizens to their representatives; theories of bicameralism; occupation; attempt to balance urban and rural power; and the preference of a majority of voters in the state. 
policy preferences. It is to foster its particular goals that each party seeks to win political office. Thus, the role of the political parties in striving to win elections is qualitatively different from that of a legislature. The interests a party can assert in unequal apportionment should be viewed in light of this difference in function.

In the weighting of convention votes by area, the political parties have two peculiar interests which no state or local governmental agency could justifiably assert. First, because of the differentiation between states in the electoral college ${ }^{75}$ and the desire to nominate a presidential candidate with nationwide support, the parties seek to foster strong state party organizations. At present this is done by the allocation of "bonus votes" to state parties which carried their state in the previous presidential, gubernatorial, or senatorial election. ${ }^{7}$ Although the bonus vote system used at present might be attacked as excessive, ${ }^{77}$ the courts should recognize a reasonable reward or incentive interest as one bearing directly on the role of parties in actively striving to win the highest public office. ${ }^{78}$

Secondly, the national parties have a vital interest in assuring full participation in the national convention by each state party. In the campaign that follows the convention, the national strategy makers rely on the state parties as important coordinating links between local and national campaign efforts. If each state party does not participate in the convention, it is unlikely to join in the campaign. The national parties seek to promote this interest in full participation by guaranteeing a minimum number of delegates to each state. ${ }^{79}$ Such allocation distorts equality of voting power among party members, ${ }^{80}$ but it serves an important function in the party's organization. The national parties remain essentially decentralized organizations which come to life only

75 See Banzhaf, One Man, 3312 Votes: A Mathematical Analysis of the Electoral College, 13 VIL.. L. REv. 304 (1968).

76 At the 1968 Democratic National Convention, each state that cast its electoral votes for the Democratic nominees for President and Vice-President in 1964 received ten bonus votes. An additional bonus vote was allowed for each 100,000 votes cast in the state for the 1964 Democratic presidential candidate. The Republicans allowed six bonus votes if a state went Republican in 1964 or if a Republican senator or governor was elected in the state between 1964 and 1968.

77 See P. David, R. Goldman \& R. Bain, The Politics of National Party Conventions 179-80 (K. Sproul ed. 1964); A. BickeL, supra note 35, at 37-39.

78 See P. Davio et al., supra note 77, at 179-80.

79 The Republicans allocate four delegates at large to each state with two additional delegates for each representative in Congress. U.S. Cong. SEN. LIBRARY, Nomination AND Election of the President and Vice-President of the United States 56 (1968). The Democrats allow three votes for each of the state's electors in the Electoral College. Id. at 46 .

80 See discussion note 89 infra. 
every four years. ${ }^{81}$ One study notes: "The president, more than any other national official, might seem to be elected by national plebiscite; but even he owes his office to having won a series of contests in state constituencies.... [T] $]$ here is perhaps no point on which writers on American politics are so generally agreed as that our state and local party organizations, taken collectively, are far more powerful than our national party organizations." 82 The guarantee of a minimum role in the convention is a formal device to help insure that these local organizations will participate fully in nominating a candidate and in the following national effort to elect the party nominee.

\section{B. Problems of Defining Party Membership: Delineating the Con- stituency}

Application of the one man, one vote doctrine to delegate selection presents a problem not encountered by the courts in the reapportionment cases. The slogan "one party member, one vote" has little meaning until "party member" is defined. ${ }^{83}$

This problem has particular relevance in regard to the allocation of convention votes by the national party. ${ }^{84}$ There are several possible bases for the allocation of votes. One suggested basis is party registration: ${ }^{85}$ each state would get a number of votes in the same proportion to the total votes as the number of registered party members in the state bears to the total number of registered party members. An initial problem with this standard is that not all state parties maintain registration lists, and many lists are outdated. But assuming that a court could order the compilation and maintenance of registration lists, this would appear at first blush to be an attractive standard. Simple analogy

81 S. Bailey, The Condmion of Our National Political Parties 4 (1959); Comm. on Political Parties, Toward a More Responsible Two-Party System, 44 AM. Poc. Scr. Rev. v (Supp. Sept. 1950); Pennock, Responsiveness, Responsibility, and Majority Rule, 46 AM. POL. SCI. REv. 790, 801 (1952).

82 A. Ranney \& W. Kendall, Democracy and the American Party System 160 (1956).

83 "What that constituency [of each party] is, however, whether it is in any sense the masses of party adherents or merely the professional party cadre, is gravely in question." A. Bickel, supra note 35, at 21. See also E. SchatrschneIder, PARTY Government 53-6I' (1942); Ranney, Toward a More Responsible Two-Party System: A Commentary, 45 AM. POL. ScI. REv. 488 (1951).

84 The member problem also has significance as to the organization of the state parties, where representation in state committees and conventions is not at present based on a one man, one vote standard. Although provision is generally made at some lower level (usually the precinct) for equal participation of all registered party members, the problems of defining membership for purposes of governance of the state party are the same as those outlined in the text with respect to allocation of convention votes.

$85 \mathrm{Cf}$. Schmid \& Whalen, supra note 70, at $1460 \mathrm{n} .92$. This was apparently the basis contemplated in Lynch v. Torquato, 343 F.2d 370 (3d Cir. 1964), and Rogers v. State Comm. of the Republican Party, 96 N.J. Super. 265 (1967). 
to the population basis for legislative apportionment by states would identify registered party members as the "citizens" of the party. The analogy, however, breaks down. Unlike citizens of the national polity, registered party members have no duties or obligations toward the party. "Citizenship" in the party is not fixed-one can change party membership at will. And even from those who do not change their registration, the party can neither demand nor expect loyalty at the polls. Only in the loosest sense can the party be understood as the creature and representative of the totality of registered party members.

More realistically, it is those who actively participate in party affairs who shape its policies and guide the success of its endeavors. Only if the typical registered party member subscribes to those policies and approves of its chosen candidate will he proclaim his identification with the party, and then only passively. ${ }^{86}$ Professor Schattschneider likens these identifiers to fans at a sporting contest. ${ }^{87}$ Defining the point at which an enthusiastic fan becomes a participant (that is, a party activist) poses a further difficult question which would involve weighing the participation of a local ward heeler against that of a national committeeman. 88

Another possible standard which would be easy to apply looks to the number of votes cast for the party candidate in the previous presidential election. ${ }^{89}$ Each state would receive a number of convention

86 Public participation in party activity is low. See generally F. GREENSTEIN, supra note 46, at 10-16; Woodward \& Roper, Political Activity of American Citizens, 44 AM. Por. Scr. REv. 872 (1950). In the sample used by Woodward \& Roper, only 75 per cent said they had voted "once or more in the last four years" and 31 per cent when asked, "Do you happen to belong to any organization that sometimes takes a stand on housing, better government, school problems, or other public issues?" answered affirmatively. Id. at 873-4.

87 E. SCHATTSCHNEIDER, supra note 83, at 55-56.

88 Even a standard as weak as occasional attendance at party meetings or functions would probably exclude large numbers of ostensible party members.

89 This was suggested as a basis in Schmidt \& WhaleN, supra note 70, at $1460 \mathrm{n} .92$.

Only after a determination of the basis from which convention votes are to be allotted can one examine mathematically the degree of malapportionment in the allocation of votes. Assuming that the number of votes cast for the party nominee in a state in the previous election is accepted as a basis and is designated " $\mathrm{S}$ "; that " $\mathrm{N}$ " is the total votes cast in the nation for the party nominee; that " $\mathrm{X}$ " is the number of votes allocated the state party for the convention; and that " $T$ " is the total number of convention votes: a perfect apportionment scheme would have $S / N=X / T$ for every state. If this basis were imposed on the delegate selection process, the national party in allocating votes for the next convention would merely plug in values for $S, N$, and $T$ and solve the equation for $\mathrm{X}$.

If this computation had been used for the 1964 Republican National Convention, for example, New York with $10.1 \%$ of the Republican voters in the 1960 presidential election would have had the same percentage of convention votes. In actuality New York controlled $7.04 \%$ of the 1964 convention vote. A complete analysis reveals the small state bias one would expect from the guarantee of a minimum number of votes to each state party. 
votes proportionate to the number of votes cast in that state for the party candidate four years earlier. But this too can be a misleading guide to party strength or to the number of usually loyal party members in the state. Basing the 1968 Republican convention vote on the 1964 Republican vote for President would have significantly misrepresented Republican strength in $1968 .{ }^{\circ 0}$ There would have been a corresponding misrepresentation for the Democrats.

Of the other possible measures of party membership-the number of votes cast for the party in a previous senatorial or gubernatorial election, the population of voting age of the state, or the population of the state ${ }^{91}$-similar criticisms could be made. In the reapportionment cases, the basis for determining equal representation was relatively clear: all those who are governed by the elected official. No such clear standard exists in dealing with political parties. The decision as to whom a political party represents and seeks to provide for in its allocation of votes would be much better made by the party itself.

\section{One Man, One Vote and the Responsible Party}

Applying the one man, one vote principle to selection of delegates to national nominating conventions would take the courts beyond the present bounds of the reapportionment cases. It is argued that such an extension of present doctrine is required to guarantee to each citizen equal participation in the nomination process so that he can "effectively" cast his vote for the President. Nevertheless, it is probable that extension of one man, one vote into this area would have other results

Twenty-five states were, by this computation, clearly overrepresented in the 1964 Republican convention. All of these states (except Texas) were in the lower two-thirds of the states, listed in order of the number of 1960 Republican voters. Though eight states (New York, California, Pennsylvania, Illinois, Ohio, Michigan, New Jersey, Indiana) cast $52.4 \%$ of the 1960 Republican vote for president, they controlled $36.6 \%$ of the 1964 convention votes. The Democrats had a similar record; their eight largest states cast $54.1 \%$ of the 1960 Democratic vote but controlled $40 \%$ of the 1964 convention votes. The figures are based on the author's data on file with the University of Chicago Law Review.

In reading these figures, one must keep in mind that they depend on a basis which is of questionable value, as is noted in the text immediately following this note. Also some degree of inequality between $S / N$ and $X / T$ is unavoidable unless fractional votes are allowed. The acceptance of any further degree of inequality would depend on whether the court accepted the party's interests-outlined in the text supra at notes 72-82-in unequal apportionment.

90 The 1968 Republican delegates would have represented more heavily the areas from which Senator Goldwater won most of his meager support in 1964. This proposed allocation basis might have made it considerably more difficult for a moderate candidate to make headway in 1968.

91 This was apparently the basis urged in Gallant v. LaFrance, 101 R.I. 299, 222 A.2d 567 (1966). 
that may outweigh and, in some cases, directly frustrate effective voter participation in presidential elections.

\section{A. Intraparty Democracy}

If the evil associated with inequalities in delegate selection power is a lack of responsiveness to the wishes of its members, it is difficult to see how the present one man, one vote doctrine can remedy this deficiency without impairing other important objectives of the national conventions. The chief criticism of the one man, one vote standard in this context is that it confuses the nomination function with the electoral function. ${ }^{92}$ The element of formalized popular control, however desirable or imperative it may be in the final choice of a President, ${ }^{93}$ is inapposite to the processes of sorting and simplifying voter alternatives and of unifying dissident members that an American political party performs through its nominating procedures.94 More concretely, imposition of one man, one vote standards is likely to reinforce public expectations that the conventions be registering, rather than deliberative, bodies; that a convention delegate should merely vote according to the mandate of those who choose him. This is what happened, and properly so, to the electoral college upon the introduction of public participation in the selection of electors. But a similar impact on party conventions would seriously impair performance of the two vital functions of simplification and unification ${ }^{95}$ and could seriously disrupt the national two party system as we know it.

1. Sorting and Simplifying Function. One major task of the nominating conventions is to pick from a number of would-be candidates

92 "[T]he essential characteristics of the nominating process differ in many important respects from those of the election choice between major-party nominees." P. DAvD, et al., supra note 77 , at 333 .

93 See generally N. Pierce, The People's President (1968) which argues strongly for abolition of the Electoral College and advocates direct election of the President and VicePresident; Banzhaf, One Man, 3.312 Votes: A Mathematical Analysis of the Electoral College, 13 Vun. L. REv. 304 (1968).

94 Concerning the functions of political parties in the nominating process, see generally P. Davm, et al., stupra note 77.

95 "[F] a party consensus on a candidate, delegations must possess a range of discretion." V.o. Key, Polttics, Parties, and Pressure Grours 412 (5th ed. 1964). "[T] he convention must be a deliberative, not a registering institution." A. Brckel, supra note 35 , at 27.

The deliberative role of delegates from California, Massachusetts, and Oregon is preempted by statute and the delegates are bound to support the primary winner, at least on the first ballot. Cal. Elections Code $\S$ 6057, 6058; Mass. Gen. Laws ANN. ch. 53, § 70I (Supp. 1969); ORE. REv. STAT. \$\$ 249.031(3), 249.221(2) (1969).

For a suggestion that the conventions have already lost their deliberative roles, see Carleton, The Revolution in the Presidential Nominating Convention, 72 PoL. ScI. Quar. 224 (1957). 
one who will receive the party endorsement and who thus will compete on relatively equal terms with the nominee of the other party. ${ }^{96} \mathrm{~A}$ candidate must satisfy two criteria: he must be able to win, and he must be able to do the job the office requires. ${ }^{97}$ As to the former, popular appeal is a significant factor. Popularization of delegate selection would inject this factor into the selection of a presidential candidate. This public appeal factor is presently measured by polls and by the few state primary elections that precede every convention, and these indicators are carefully considered by party leaders and convention delegates as they choose a presidential nominee..$^{88}$

Against this popular appeal factor is placed the more important requirement that the party candidate, if elected, be able to perform well the chores of the presidency. Elitists would sense a danger of decreasing emphasis on competency in any democratization of the nomination procedures. Such mistrust of "the People" is not readily accepted today. ${ }^{99}$ However, the information cost to each voter of evaluating the relative competence of a large number of potential candidates, in light of the non-political demands on his time, might be so high that their individual judgments as to a candidate's competence would be hasty and ill considered. Even at present, when the choice must be made between only two presidential candidates, general knowledge of candidates and issues is low. ${ }^{100}$

Our political system compensates for this high information cost by leaving to the political parties the task of sorting through the number of possible candidates to find two who will be competent presidents, thus simplifying for the voter the electoral decision. Convention delegates and party leaders under the current arrangement "are quite concerned about selecting suitable officeholders since it is assumed that the actions and identities of these men will in the long run marginally determine the extent and location of the party's appeal within the electorate, and its record of success at the polls." 101 The party activists scrupulously take account of competence because it affects their stake in the future of the party. ${ }^{102}$

96 P. DAvin, et al., supra note 77, at 321-2.

$07 \mathrm{Id}$. at 322.

98 See V.O. Kex, Polmtics, Parties, and Pressure Groups 412 (5th ed. 1964); Carleton, The Revolution in the Presidential Nominating Convention, 72 POL. SCI. QuAR. 224 (1957).

90 Cf. V.O. KEY, The Responstble Electorate (1966).

100 See F. GreENSTEIN, supra note 46, at 5-17; note 86 supra.

101 N. Polsby \& A. Wildavsky, Presidential Elections 21 (1964).

102 Contrary to the assertion of some observers-see Note, The Presidential Nomination: Equal Protection at the Grass Roots, 42 S. CAL, L. REv. 169, 176 (1968)-that the Republican nomination of Goldwater in 1964 resulted from a failure of party leaders to heed rank and file sentiments, Professor John May of the University of Chicago asserts 
To impose popularization on the parties would mean that new groups ${ }^{103}$-analogous to the present parties - would be needed to define the competence and policy positions of competitors for the nomination so that the mass of party members could intelligently choose their candidate. Such proliferation of new groups is certainly unnecessary to guarantee selection of competent candidates. ${ }^{104}$ Even if these subgroups were formed, the actual nomination of the candidate by popularized means would tend to "throw nomination into the hands of those whose stake in the workings of the political process is not great enough to insure that the eventual nominee was qualified for the Presidency by experience, qualities of mind, or by virtue of political alliances with others professionally engaged in political activity."105

2. Unifying Function. Once a candidate is chosen, it is essential to his success in campaigning for the presidency that he receive as full a measure of support from within the party as possible. After bitter nomination contests, it is often a difficult task to reconcile various factions and unite them behind the party nominee. Any factor that accentuates factional differences would seriously impede reunification. Conceiving of the conventions as mere registering institutions is likely to have just such an effect. A delegate who simply registers the will of those who elected him will not be inclined to take it upon himself to announce that he and the structural unit of the party he represents (precinct, county, state) will use its resources wholeheartedly to support the party nominee if that nominee is not the man he was directed to back. After a close contest, the split between the two leading contenders may be irreparable, for individual delegates on the losing side would have no independent position from which to bargain and win concessions from the victor. Also, it would be clear to individual party members that their preference had been rejected by the group as a whole. The early identification with one candidate may outweigh party iden-

that the nomination was the work not of party professionals, but of "passionate amateurs who became delegates." Interview, Oct. 20, 1969. See also G. Pomper, Nominating THE President 272 (1968), discussing the Goldwater nomination, who writes, "Voter opinion was disregarded by delegates."

103 Such groups are commonly termed party factions. On the possible ill effects of accentuation of party faction, see text infra at notes 106-14.

104 P. David, et al., supra note 77, at 323. N. PolsBy \& A. WiLdavskx, supra note 101, at 161 , contends: "The nominee whose sole virtue is his innocuousness or pleasant smile seems to have disappeared."

105 N. Polsby \& A. Wildavsky, supra note 101, at 155, speaking of proposals for expansion of direct presidential primaries. Viewing the desirability of popular control of nominating conventions, P. DAvid, et al., supra note 77, at 333 , senses a danger of deemphasis of "such other virtues as stability, competence, foresight, and a gifted leadership." 
tification so that the disappointed individuals will either assume an indifferent stance as to the remainder of the electoral process, or will join with others to establish independent organizations for the promotion of the man who, despite their support, lost the major party nomination.

This tendency to accentuate party factionalism is an often noted consequence of making nomination a matter of popular selection. ${ }^{106}$ This effect was indicated earlier with respect to the imposition of primaries on state parties. ${ }^{107}$ Such accentuation endangers the national two party system itself. ${ }^{108}$ If even one of the national parties developed strong opposing factions, one of two consequences would follow. First, since the factionalized party could not command its full manpower and financial resources in support of one candidate, the presidential election might go to the unified party almost by default. ${ }^{109} \mathrm{Or}$, if each faction of the disunified party campaigned for its man or issue, thus presenting more than two strong candidates to the electorate, the chance that no nominee would win an electoral majority would significantly increase. ${ }^{110}$ Under present provisions, the electoral college, or failing that, the House of Representatives, ${ }^{111}$ would then decide the election. In a political system that values active competition between political parties of equal strength ${ }^{112}$ and election of a President by a majority

106 Ranney, Toward a More Responsible Two-Party System: A Commentary, 45 AM. Pol. ScI. REv. 488, 491-2 (1951); cf. N. Polsby \& A. WudAvsKy, supra note 101, at 154-5.

107 See text supra at notes 47-49.

108 The value of a national party system with only two major parties is not obvious and perhaps for this reason easily underestimated. The primary incident of a two party system is its contribution in mitigating divisive conflict within Congress and between the branches of the federal government. See note 120 infra. An extensive defense of the national two party system is beyond the scope of this comment, but it is interesting to note that SChatTSCHNEIDER, supra note 83 , at 67 , sees no need to argue the merits of having a two party rather than a multiparty system, because a two party system is "inevitable in the United States regardless of the personal preferences of individual critics. We could not discard the two-party system and adopt a multiparty system in the United States . . . even if we wanted to do so."

108 Cf. the statement of V.O. Key, Politics, Parties, and Pressure Groups 346 (5th ed. 1964): "[T]t may well be that intraparty democracy tends to encourage the development of one-partyism and to make the politics of many states and cities, not a party politics, but a politics of factions, cliques, and individuals with amorphous popular followings."

110 Though his opinion allowed a third party access to the ballot, Mr. Justice Black in Rhodes v. Williams, 393 U.S. 23, 32 (1968), admitted: "[T] $]$ he State does have an interest in attempting to see that the election winner be the choice of a majority of the voters." The third party plays an important role in our political system while not endangering the desire for selection of a President by a majority vote. Cf. A. BrCKEL, supra note 35, at $42-50$.

111 Each state casting one vote, clearly not in line with population variances. See U.S. Const. amend. XII, superseding art. II, § 3.

112 See note 120 infra. 
vote, ${ }^{113}$ the scenario is not pleasant. ${ }^{114}$ The danger of impairment of the capacity to unify should prompt careful reconsideration of extension, through one man, one vote doctrine, of popular control of nominating processes.

\section{B. Responsiveness to the General Electorate}

The present delegate selection processes are also said to obstruct responsiveness of the parties to the American electorate as a whole. ${ }^{115}$ The main thrust of this charge is that the parties have failed to present clear alternatives to the voters; the voters have no real choice.118

The traditional proposal for improving the clarity of electoral alternatives and for enhancing the accountability of the parties to the electorate is for the parties to adopt a strict program or policy orientation which is distinct from the platforms of other parties and to foster disciplined adherence to this party platform. ${ }^{117}$ The model for this sort of party accountability is Britain's party system. ${ }^{118}$ Proponents argue that the electoral choice would be simplified by the adoption of such a party system, with a correlative increase in the degree of popular participation in the political process. ${ }^{119}$

113 This value is based less on a belief that a man who wins a majority vote is more capable of being President than on a notion that the President should be a representative of all the people. Andrew Jackson was probably the first to use this notion to justify expansion of presidential power. See A. KellX \&: W. HARBIson, The AMERICAN Constitution $335-42$ (1963).

114 Unless one believes that if the factions took distinct policy positions voter choices would be easier. But see notes 116, 120 infra.

115 Note, Regulation of Political Parties: Vote Dilution in the Presidential Nomination Procedure, 54 Iowa L. Rev. 471 (1968); Note, The Presidential Nomination: Equal Protection at the Grass Roots, 42 S. CAL. L. Rev. 169, 170 (1968).

116 The short answer is that there is a choice. There most probably was a substantive difference in policy pursuits as a result of the selection of a Kennedy over a Nixon, a Johnson over a Goldwater, or a Nixon over a Humphrey. Furthermore, national party platforms show major differences. In 1968, the Democratic and Republican platforms differed on Vietnam war policy and law and order issues. It can safely be said that the Democrats were more hawkish as to Vietnam and more liberal on domestic policies than were the Republicans. The attitude of "no choice" may well result not from lack of substantive choice but from a failure of the parties to articulate the choice. Given the goal of majority support to put a man in the Presidency and the multi-faceted nature of our society, this non-articulation of party differences may be a structural necessity, unremediable without drastic alteration of the whole party system. See note 120 infra.

117 See Comm. on Political Parties, Toward a More Responsible Two-Party System, 44 AM. Pol. Scr. REv. (Supp. Sept. 1950) [hereinafter cited as REPORT of THE Comm. oN Polrtical Parties]. This report sparked a lively discussion at the time. See authorities cited note 120 infra. But since then, the issue has received little attention.

118 A. Ranney \& W. Kendall, Democragy and the American Party System 527-30 (1956).

119 See Report of the Comm. on Political Parties 15. 
There is extensive criticism of reform along these lines. ${ }^{120}$ Even if policy orientation is accepted as a method of increasing responsiveness to the general community, there remains a question of the utility of intraparty democracy as a part of the reform. "[I]t is difficult to see how the . . notion of 'intraparty democracy' is calculated to promote achievement of ... the 'external' responsibility of the parties to the whole community."121 Pursuit of intraparty democracy even in a policy oriented party would be a failure to recognize "the possibilities for promoting factionalism in the parties by trying to make them into something other than purely private associations." 122

120 The arguments over the desirability of a policy orientation and centralization of political parties are somewhat complex. For purposes of clarity, the position as to reform along these lines from which this comment proceeds should be explained.

The political parties in the United States do not, and perhaps cannot, function as do those in Britain. One party cannot clearly be labeled "conservative" and the other "liberal." Because the desire to seek consensus, or majority, support is sought to be fulfilled in a society with many distinct interest groups and many shades of opinion on major issues, both parties seek a common ground in which a majority of voters will coalesce. This is a common phenomenon in presidential elections; as election day draws near, both major candidates modify their positions to bring them more in line with the middle-of-the-road "swing" voters who often determine an election.

But neither the party nor its presidential candidate can depart too far from the positions of those who provide the party's bedrock support. The views of the party faithful limit deviation from those interests with which the party is associated; for the presidential candidate, these limits operate during the election and, if he is elected, during his administration. Thus, the choice of the American voter is generally between liberal (Democratic Party) and conservative (Republican Party) tendencies. It is only the "center of gravity" of each party that differs; but they do differ.

In the United States, this similarity of party positions promotes the stability of the government itself. In Britain, if a party wins an election, it should be able to implement its policy stands because it controls the body responsible for governmental policy making. The British party can afford to take distinct policy stands. Having had control of government policy, if the party is unsuccessful in implementing its goals, it is totally accountable to the voters. Another party can be given control of the government. Neither American party can so readily be held accountable to the electorate for the course of governmental actions; this is one cost of the separation of powers concept on which the federal government is based. Even in extreme periods of one-party dominance, both parties retain and exercise some control over governmental affairs. If the business of government is to go on without bitter and divisive strife within and between the branches of government, the parties must agree on a broad range of values and goals.

A. RANNEY \& W. KeNDALL, supra note 118 , at $527 \mathrm{n} .15$, lists these as the "leading general defenses of our present party system": P. HerRing, ThE Polttics of DEMOcracy (1940); H. Agar, The Price of Union (1950); E. Griffith, Congress: Its Contemporary Role (1951). For critical analysis of the Report of the CoMnM. on Polrtical Parties, see Ranney, Toward A More Responsible Two-Party System: A Commentary, 45 AM. Pol. Scr. REv. 488 (1951); Turner, Responsible Parties: A Dissent from the Floor, 45 AM. PoL. Scr. Rev. 143 (1951).

121 Ranney, Toward a More Responsible Two-Party System: A Commentary, 45 AM. PoL. Scr. REv. 488, 491 (1951).

122 Id. at $491-2$. 
A leading proponent of the policy orientation reform, Professor Schattschneider, ${ }^{123}$ summed up the objection to intraparty democracy this way: ${ }^{124}$

The parties do not need laws to make them sensitive to the wishes of the voters any more than we need laws compelling merchants to please their customers. The sovereignty of the voter consists in his freedom of choice just as the sovereignty of the consumer in the economic system consists in his freedom to trade in a competitive market. That is enough; little can be added to it by inventing an imaginary membership in a fictitious party association. Democracy is not to be found in the parties but between the parties.

\section{CoNCLusion}

The tradition of non-interference with political parties is a strong one. A recognition of functional differences between the nomination and election aspects of the presidential selection process should persuade the courts not to break this tradition. The one man, one vote standard with its implication of mathematical precision would allow the parties too little leeway in building, maintaining, and fostering a nationwide coalition of interests that will work within the party organization to effectuate political goals by winning public office. As a method of promoting intraparty democracy, application of one man, one vote could be a step leading to drastic reshaping of the building blocks of our political system. It is not at all clear that such judicial reshaping is needed.

\footnotetext{
123 Schattschneider was chairman of the group which prepared the REPORT OF THE Comm. on Political Parties.

124 E. SChatTSChNeIDER, supra note 83 , at 60.
} 